Jurnal Indonesia Sosial Teknologi:p-ISSN: 2723 - 6609

e-ISSN :2745-5254

Vol. 2, No.12 Desember 2021

\title{
PENGGUNAAN MULTIMEDIA SEBAGAI SARANA PEMASARAN KIDDIPOSH
}

Anggun A'yunn Angraeny', Adrian Alexander Suripatty ${ }^{2}$

Program Studi Komputer Multimedia Politeknik Piksi Ganesha, Indonesia ${ }^{1,2}$

Email: anggunaangraeny@gmail.com ${ }^{1}$, adriansuripatty@gmail.com ${ }^{2}$

\begin{abstract}
Abstrak
E-Commerce menjadi strategi pemasaran yang menjadi pilihan Kiddiposh dengan berbagai media yang digunakan, seperti penggunana website, social media, dan marketplace. Hal tersebut karena semakin banyaknya pengguna sarana digital yang juga dapat memberikan dampak positif pada penjualan produk Kiddiposh. Tujuan dalam penelitian ini adalah menganalisis penggunaan multimedia sebagai sarana pemasaran Kiddiposh. Metode penelitian ini menggunakan metode kualitatif dengan pendekatan studikasus dan Kiddiposh sebagai objek dalam penelitian. Penentuan lokasi penelitian dengan pertimbangan bahwa Kididposh merupakan salah satu bidang usaha yang menggunakan multimedia dalam kegiatan usahanya. Waktu penelitian dilakukan pada bulan Agustus dan September 2021. Data yang digunakan adalah data primer dan sekunder dengan menggunakan analisis interactive model yang diklasifikasikan dalam tiga langkah yaitu reduksi data, penyajian data, dan penarikan kesimpulan. Hasil dalam penelitian ini menunjukan bahwa Kiddiposh menggunakan media E-Commerce berupa website, social media Instagram, dan marketplace shopee dalam menawarkan produknya. Statistic kunjungan konsumen pada media E-Commerce Kiddiposh mengalami peningkatan setiap tahunnya. Hal tersebut diikuti dengan peningkatan penjualan produk Kiddiposh setiap tahunnya.
\end{abstract}

Kata kunci: E-Commerce, social media, marketplace, dan website

\section{Abstract}

E-Commerce is a marketing strategy that is Kiddiposh's choice with various media used, such as website users, social media, and marketplaces. This is because the increasing number of digital users can also have a positive impact on selling Kiddiposh products. The purpose of this research is to analyze the use of multimedia as a marketing tool for Kiddiposh. This research method uses a qualitative method with a case study approach and Kiddiposh as the object of the research. Determination of the research location with the consideration that Kididposh is one of the business fields that uses multimedia in its business activities. The time of the research was carried out in August and September 2021. The data used were primary and secondary data using interactive model analysis which was classified into three steps, namely data reduction, data presentation, and drawing conclusions. The results in this study indicate that Kiddiposh uses E-Commerce media in the form of websites, Instagram social media, and shopee marketplaces in offering their products. The statistics on consumer visits to Kiddiposh's E-Commerce media have 
increased every year. This is followed by an increase in sales of Kiddiposh products every year

Keywords: E-Commerce, social media, marketplace, and website

\section{Pendahuluan}

Indonesia saat ini mulai memasuki Era Digital 4.0 yang menyebabkan perkembangan teknologi dari hari kehari semakin mengalami peningkatan (Sedana, 2019). Era digital 4.0 menjadi masa saat berbagai macam kegiatan atau hal yang dilakukan oleh manusia dapat dengan mudah dilakukan dengan support yang diberikan oleh teknologi. Teknologi dimanfaatkan oleh setiap individu untuk memperoleh kebutuhan mereka, sehingga saat ini teknologi menjadi faktor utama yang dicari dan ditemukan oleh individu untuk mempermudah segala kegiatan yang dilakukan dimasyarakat (Alyusi, 2019). Teknologi tidak hanya dirasakan dalam kehidupan seharihari setiap individu, namun juga dirasakan oleh sebuah organisasi.

Pemanfaatan teknologi dilakukan oleh organisasi dirasakan dengan menggunakan teknologi sebagai media pemasaran dan promosi suatu produk (Suryani, 2014). Pemasaran dimulai dengan pemenuhan kebutuhan manusia yang kemudian tumbuh menjadi keinginan manusia. Keinginan manusia terhadap suatu produk akan menjadi perhatian bagi para pelaku usaha, sehingga akan menggunakan daya upaya untuk mendekatkan kepada calon konsumennya.

Dalam sebuah pemasaran suatu produk tidak terlepas dari adanya suatu komunikasi antara pemasar dan konsumen. Saat ini komunikasi yang dijalankan oleh pelaku usaha dan konsumen tidak hanya dalam bentuk komunikasi secara langsung, namun juga dapat dilakukan menggunakan teknologi yaitu secara online (Siswanto, 2013). Pemanfaatan teknologi yang berkembang saat ini komunikasi tersebut akan dapat dijangkau dimanapun dan kapanpun.

Pemasaran yang dilakukan melalui sebuah teknologi dirasa memiliki keuntungan yang dapat dipertimbangkan. Faktor utama seorang pelaku usaha yang memilih untuk menggunakan teknologi sebagai media pemasaran karena biaya yang dikeluarkan tidak dalam jumlah besar dan tidak dibatasi oleh ruang dan waktu (Syahputro, 2020). Konsumen akan dapat melihat produk yang dijual kapan dan dimana saja, sehingga akan lebih berpeluang untuk dapat menjangkau target pasar dalam skala yang besar.

Kebutuhan konsumen yang tidak terbatas menjadi dasar bagi para pelaku usaha untuk melalukan strategi pemasaran yang tepat sesuai dengan target konsumen yang dituju, seperti peralihan dari perdagangan tradisional menjadi perdagangan online (Electronic Commerce) (Cicik Harini, 2020). Seiring perkembangannya E-Commerce dianggap sebagai kanal komunikasi antara pelaku usaha dan konsumen. Kegiatan $E$ Commerce yang dilakukan oleh pelaku usaha berbeda-beda menyesuaikan dengan target pasar, seperti market place, website, dan social media.

Pemasaran melalui marketplace memungkinkan setiap individu untuk menjadi pelaku usaha hanya dengan bermodalkan produk yang akan dijual. Namun, informasi terkait produk yang dijual hanya dapat disampaikan oleh pelaku usaha secara singkat, 
sehingga menjadi tantangan bagi pelaku usaha untuk mendapatkan kepercayaan dari konsumen. Sebelum berkembangnnya marketplace, website menjadi salah satu media pemasaran online yang juga sering digunakan oleh beberapa brand. Website menjadi media yang menjelaskan sebuah brand secara spesifik dengan ciri khasnya masingmasing, karena website bersifat pribadi untuk suatu brand yang tidak dapat digabungkan dengan brand lainnya, sehingga konsumen akan lebih focus terhadap produk yang ditawarkan. (Hastanti \& Purnama, 2015) menyatakan bahwa mempromosikan produk dengan menggunakan website akan memberikan keuntungan juga mempermudah dalam meningkatkan perkembangan usaha dan dapat menghemat biaya. Konsumen lebih mudah memilih produk tanpa harus datang langsung.

Seiring perkembangan teknologi dan perubahan perilaku penggunaan internet, social media tidak hanya digunakan sebagai sarana berkomunikasi antara individu tetapi juga digunakan sebagai media pemasaran produk. Media sosial digunakan sebagai alat komunikasi pemasaran untuk meningkatkan kesadaran konsumen terhadap produk, meningkatkan image produk, dan berakhir pada peningkatan penjualan (Kotler \& Keller, 2016). Media E-Commerce yang digunakan oleh pelaku usaha tersebut memudahkan para pelaku usaha untuk memulai usahanya tanpa perlu menyewa tempat untuk membuka menjual produknya.

Kiddiposh menjadi salah satu usaha yang melihat peluang besar dari pemanfaatan teknologi dalam kegiatan pemasaran. Kiddiposh adalah brand yang menawarkan produk perlengkapan bayi seperti perlengkapan makan, perlengkapan tidur, dan perlengkapan pakaian. Target pasar yang ingin dicapai oleh Kiddiposh adalah seluruh konsumen yang memiliki kebutuhan akan perlengkapan bayi tanpa dibatasi oleh ruang dan waktu, sehingga sejak tahun 2019 hingga saat ini Kiddiposh memilih untuk memasarkan produknya melalui E-Commerce. Media E-Commerce yang digunakan oleh Kiddiposh adalah website, social media Instagram, dan marketplace shopee.

Kiddiposh menggunakan website sebagai media pemasaran pribadi yang menjelaskan secara detail terkait seluruh produk yang ditawarkan. Website tersebut memudahkan konsumen untuk memperoleh informasi terkait produk Kiddiposh. Social media Instagram adalah salah satu media social yang banyak digunakan individu atau perusahaan dalam melakukan penjualan produk. Instagram adalah media sosial yang menawarkan berbagai macam fitur dan fasilitas yang berbeda dengan media sosial pendahulunya. Saat ini Instagram memiliki jumlah pengguna aktif dengan pertumbuhan yang lebih pesat dari pada Facebook. Pada kuartal keempat 2013, tercatat Facebook hanya memiliki pertumbuhan pengguna aktif sebesar 3 persen, sedangkan Instagram mencapai 23 persen (Pramudita, 2019). Media yang juga digunakan oleh Kiddiposh adalah marketplace shopee. Marketplace sering kali menjadi pilihan para konsumen karena kemudahan pembayaran dan banyaknya promo-promo seperti gratis ongkir.

Hal ini sejalan dengan penelitian (Puspitarini \& Nuraeni, 2019) yang juga menjelaskan pemanfaatan media sosial seperti Instagram dan Website sebagai media promosi. Pemilihan instagram sebagai media promosi yang aktif didasari oleh alasan bahwa instagram memiliki kepraktisan dan memberikan manfaat terhadap penjualan 
yaitu hanya dengan mengunggah foto ataupun video produk ke akun instagram, kemudian foto tersebut dilihat oleh konsumen dan konsumen tertarik untuk membeli. Kegiatan direct marketing yang dilakukan dalam instagram adalah mencantumkan nomor telepon, alamat email, website, petunjuk arah pada profil instagram dan juga section yang memperlihatkan produk. Selain itu, (Augustinah, 2019) juga melakukan penelitian terkait pemanfatan media sosial sebagai sarana promosi, namun berbeda dengan penelitian penulis yaitu yang mana didalam penelitian tersebut membahas terkait media sosial apa saja yang memiliki pengaruh paling besar terhadap kegiatan promosi dan menarik konsumen.

Penelitian tersebut menggambarkan bahwa Kiddiposh aktif mengikuti perkembangan zaman dalam menentukan media promosi dalam penjualan yang memberikan berbagai kemudahan bagi konsumen. Kemudahan yang ditawarkan oleh Kiddiposh dalam membantu konsumen memperoleh kebutuhan produk perlengkapan bayi tersebut diharapkan dapat meningkatkan tujuan utama dari kegiatan pemasaran. Oleh karena itu, penelitian ini dilakukan untuk mengetahui penggunaan multimedia sebagai media pemasaran Kiddiposh.

\section{Metode Penelitian}

Metode penelitian yang dilakukan dalam penelitian ini adalah metode kualitatif. Metode kualitatif yang dilakukan berperan sebagai prosedur penelitian yang menghasilkan data desktriptif berupa kata kata tertulis atau secara lisan dari pihak-pihak yang terlibat sebagai pemberi informasi

Menurut (Sukmadinata, 2011), penelitian deskriptif kualitatif ditujukan untuk mendeskripsikan dan menggambarkan fenomena yang ada, baik bersifat alamiah maupun rekayasa manusia yang lebih memperhatikan mengenai karakteristik, kualitas, keterkaitan antar kegiatan. Penelitian ini secara spesifik diarahkan pada penggunaan metode studi kasusya itu penelitian yang memusat secara intensif terhadap suatu objek. (Nursalam \& Arifin, 2016) menyatakan bahwa metode penelitian studi kasus adalah penelitian yang mencakup pengkajian dengan bertujuan untuk memberikan gambaran secara mendetail mengenai latar belakang, sifat maupun karakter yang menjadi objek dalam penelitian.

Lokasi dalam penelitian ini adalah Kiddiposh yang ditentukan secara sengaja dengan pertimbangan bahwa Kiddiposh sebagai salah satu brand usaha yang mampu memanfaatkan multimedia dalam pemasaran produknya. Sejak tahun 2019 hingga saat ini Kiddiposh sudah mampu menjangkau target pasarnya hanya dengan menggunakan beberapa media dalam dunia E-Commerce yaitu website dan social media. Waktu pelaksanaan penelitian ini adalah pada bulan Agustus hingga September 2021. Teknik pengambilan data dilakukan dengan menganalisa perkembangan Kiddiposh dalam menggunakan multimedia terhadap kondisi usaha Kiddiposh, Data yang digunakan dalam penelitian ini adalah data primer dan sekunder. Data primer di peroleh dari hasil wawancara dengan responden. Data sekunder diperoleh dari sumber literatur, instansi dan lembaga terkait. Dalam pengumpulan data dilapangan penulis menggunakan tehnik sebagai berikut: 
1. Metode obsevasi atau pengamatan (observation reserch) yaitu pengumpulan data dengan cara mengadakan pengamatan langsung ke obyek penelitian.

2. Kuisioner atau angket (quesioner) yaitu daftar pertanyaan yang telah disusun sedemikian rupa dengan pemberian bobot serta petunjuk pengisian.

3. Penelitian Kepustakaan (library reserch). Penelitian kepustakaan dalam arti penelitian mengumpulkan data-data dengan mencari kelengkapan dasar teori.

Analisis data adalah kegiatan menyusun urutan data, mengorganisasikan kedalam sebuah pola tertentu, melakukan kategorisasi sesuai kriterianya masing-masing, dan hasil yang dapat disajikan. Menurut (Moleong, 2007) analisis data adalah upaya yang dilakukan dengan jalan bekerja dengan data, mengorganisasikan data, memilahmilahnya menjadi satuan yang dapat dikelola, mensin tesisnya, mencari dan menemukan pola, menemukan apa yang penting dan apa yang dipelajari, dan memutuskan apa yang dapat diceriterakan pada orang lain.

Teknik analisis data yang digunakan dalam penelitian ini adalah interactive model yang diklasifikasikan dalam tiga langkah yaitu.

1. Reduksi data

Reduksi data adalah kegiatan pemilihan, perusahan perhatian pada penyederhanaan, pengabstrakan, dan transportasi data kasar dari catatan tertulis di lapangan menjadi data yang mudah dipahami

2. Penyajian data

Data disajikan menyesuaikan dengan pesan apa yang akan disampaikan oleh penulis, agar pembacanya dapat mengerti terkait permasalahan yang diangkat oleh penulis.

3. Penarikan kesimpulan

Hasil dari penyajian data yang sesuaikan menghasilkan sebuah kesimpulan yang dapat diambil sesuai dengan topik pembahasan penelitian.

\section{Hasil dan Pembahasan}

Kiddiposh adalah salah satu brand yang memenuhi kebutuhan konsumen terkait perlengkapan anak. Produk yang ditawarkan Kiddiposh mulai dari pakaian bermain kasual hingga gaun acara khusus, perlengkapan bayi hingga taman bermain anak, dari busana bayi baru lahir hingga kebutuhan anak-anak. Kiddiposh berkomitmen bahwa layanan yang dimiliki Kiddiposh dapat menghubungkan orang tua dan merek fashion anak-anak diseluruh wilayah negeri hanya dalam waktu yang singkat. Dalam mewujudkan apa yang menjadi tujuan Kiddiposh, maka para pengelola Kiddiposh memutuskan untuk menggunakan multimedia untuk masuk ke dunia E-Commerce. Media E-Commerce yang dimanfaatkan oleh Kiddiposh adalah website dan social media Instagram.

\section{Website Kiddiposh}

Kiddiposh memiliki website pribadi yang dikelola untuk menawarkan produknya. Website tersebut bersifat umum atau dapat diakses dan dilihat oleh 
siapapun hanya dengan mengunjungi laman www.kiddiposh.com. Website adalah perpustakaan online mengenal informasi pelanggan selain menjadi pasar di mana barang dan jasa dibeli. Web memiliki pengaruh luar biasa pada pembelian off line, lebih dari $80 \%$ pembeli mobil baru meneliti mobil impian

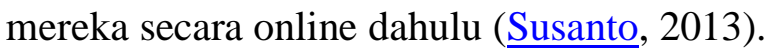

Website digunakan sebagai media pemasaran dengan beberapa pertimbangan yang dilakukan. Website yang terdiri dari server web, server aplikasi, dan server basis data sangat memiliki peluang dalam mendukung peningkatan penjualan dan mencapai target pasar Kiddiposh.

Hal Tersebut menyebabkan pelaku usaha Kiddiposh memutuskan untuk menjadi web sebagai strategi pemasaran. Sejalan dengan penelitian (Haryono, 2018), yang menyatakan bahwa penggunaan website berpengaruh positif terhadap penjualan suatu produk. Promosi suatu produk akan lebih optimal hasilnya apabila periklanan yang dilakukan pada media internet juga diimbangi dengan tingginya pemasaran melalui website, maka pemprosesan informasi oleh konsumen akan semakin baik.

Strategi pemasaran terdiri dari berbagai langkah yaitu mulai dari pemilihan pasar, perencanaan produk, penetapan harga, sistem distribusi, dan komunikasi pemasaran. Penggunaan website mendukung strategi pemasaran dalam hal komunikasi pemasaran.

Website berperan sebagai media interaksi antara Kiddiposh dengan konsumen, melalui website tersebut konsumen akan dapat memperoleh beberapa informasi terkait produk yaitu fashion anak dengan beberapa kategori umur, harga yang ditawarkan, perbedaan satu produk dengan produk lainnya yang serupa. Selain itu, melalui website Kiddiposh juga terdapat layanan untuk konsumen dalam berkomunikasi dengan Kiddiposh.

Website di desain dengan semenarik mungkin menyesuaikan dengan target pasar yang akan dicapai oleh Kiddiposh yaitu keluarga. Tampilan website Kiddiposh dilengkapi dengan fitur menu yang berisikan beberapa kategori produk yang ditawarkan Kiddiposh mulai dari produk untuk bayi usai 0 bulan hingga anak usia 13 tahun. Sebagai langkah promosi, Kiddiposh juga menampilkan beberapa informasi promo yang ada di Kiddiposh. Hal tersebut dilakukan sebagai langkah untuk dapat menarik minat konsumen dalam melakukan pembelian. Pada halaman awal website Kiddiposh juga terdapat beberapa informasi lainnya yang dapat ditemukan dengan mudah oleh konsumen, seperti langkah melakukan pembayaran, konformasi pembayaran, proses pembatalan pesanan, dan sebagainya.

Sejalan dengan penelitian (Wanda, 2017) yang menyatakan bahwa kualitas informasi yang disampaikan dalam sebuah website dapat mempengaruhi minat konsumen dalam melakukan pembelian atas produk yang ditawarkan. Selain itu dalam penelitiannya juga menjelaskan bahwa manfaat bersih dari penggunaan website menjadi faktor yang mempengaruhi 
penjualan. Manfaat bersih yang dimaksud adalah peningkatan dukungan dan pelayanan pelanggan, pengetahuan pelanggan, pengalaman pelanggan, jangkauan global dan kesadaran merek.

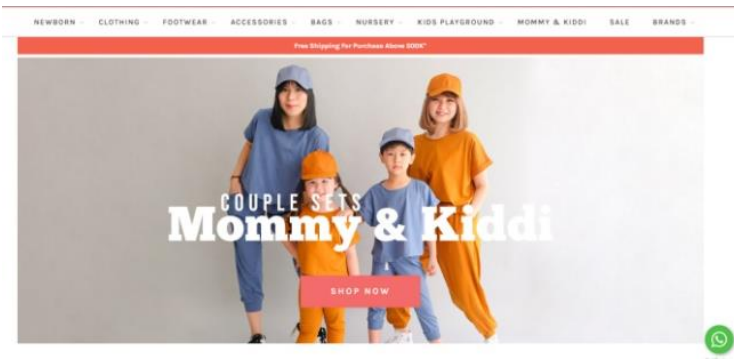

Gambar 1. Tampilanawal website Kiddipost

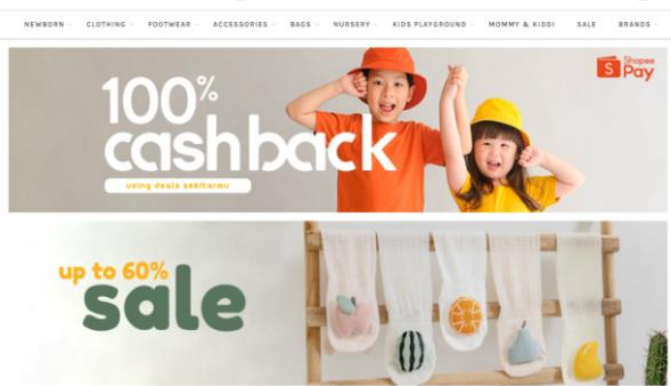

Gambar 2. Informasi promo pada website Kiddiposh.

Kesadaran konsumen terhadap sebuah merek menjadi pokok perhatian yang harus disiapkan oleh pelaku usaha. Konsumen akan menyadari dan selalu ingat akan suatu merek juga mampu memberikan kesan yang baik kepada konsumen, karena konsumen akan merasa lebih mengenal merek tersebut. Ketika seorang konsumen menyadari suatu merek maka terdapat kemungkinan akan terjadinya pembelian secara berulang. Tagline seharusnya dimiliki oleh setiap merek usaha, karena sebagai pembeda dengan merek lainnya yang menjual produk yang serupa. Kiddiposh dalam menjalankan usahanya menggunakan tagline "One stop shop for your adorable ones". Hal ini sejalan penelitian (Radjaban, Dewi, \& Rianto, 2021) yang menyatakan bahwa Tagline menjadihal pokok yang harus dipikirkan oleh para pelaku bisnis dalam memperkenalkan produknya kepada konsumen.

2. Intagram Kiddiposh

Kegiatan E-Commerce yang dilakukan oleh Kiddiposh tidak hanya melalui website saja, tetapi juga melalui social media. Hal tersebut dilakukan agar jangkauan konsumen yang dicapai oleh Kiddiposh menjadi lebih besar lagi yaitu konsumen yang menggunakan social media dalam sebuah transaksi.

Semakin meningkatnya pengguna ponsel, maka memanfaatkan media yang ada dalam dunia digital menjadi sebuah peluang yang dapat dilakukan oleh para pelaku bisnis. Sebuah pesan pemasaran atau konten yang disajikan oleh pelaku bisnis harus dapat menarik perhatian pada calon konsumen. 
Instagram merupakan salah satu social media yang digunakan sebagai tempat untuk berbagi gambar yang kini telah berkembang menjadi salah satu alat pemasaran yang paling efektif dalam menjual produk.

Efektivitas ini taklepas dari gambar yang di bagikan melalui akun Instagram tersebut. Kekuatan visual dianggap lebih mempunyai daya Tarik untuk membawa konsumen melakukan konversi dibandingkan dengan cara lainnya.

Pemasaran yang dilakukan oleh Kiddiposh di social media Instagram bertujuan untuk memberikan informasi mengenai produk-produk yang ditawarkan Kiddiposh, berinteraksi dengan pelanggan agar hubungan prapembelian dan pasca pembelian masih terjaga dengan baik, membangun kepercayaan dengan konsumen atas produk Kiddiposh, serta beberapa informasi lainnya yang berhubungan dengan bidang usaha Kiddiposh.

Kiddiposh dalam mengelola Instagram melakukan kegiatan utama yaitu membuat konten. Konten yang dibuat oleh Kiddiposh bertujuan untuk mencari engagement agar konten yang dibuat dapat menarik perhatian konsumen.

Konten yang dapat dibuat oleh Kiddiposh terdiri dari giveaway, video reels, quiz interaktif, sesi tanya jawab, dan sebagainya. Seluruh konten yang akan diupload pada Instagram Kiddiposh akan didesain secara menarik terlebih dahulu, agar pesan yang akan disampaikan dapat dipahami oleh konsumen.

Instagram menjadi salah satu social media yang dipilih oleh Kiddiposh karena memiliki fitur yang menarik, yaitu

a. Followers (pengikut)

Fitur ini memfasilitasi para calon pembeli untuk dapat mengikuti perkembangan dari social media milik Kiddiposh. Konsumen yang menjadi followers Kiddiposh di Instagram akan memperoleh informasi yang lebih cepat, karena Kiddiposh akan menjalin pertemanan dengan konsumen tersebut di social media Instagram.

b. Upload foto

Foto suatu produk menjadi hal yang penting untuk dimiliki oleh pelaku usaha, karena dengan adanya foto terkait produk akan memberikan kepercayaan kepada konsumen. Foto yang sudah di upload pada social media Kiddiposh akan menjadi display produk yang ditawarkan Kiddiposh. Konsumen akan memiliki penilaiannya sendiri saat sudah adanya pemesaran atas suatu produk.

c. Judul foto (caption)

Dalam hal ini penulisan caption dapat disebut Copy Writing. Pelaku usaha akan memikirkan dengan matang terkait tulisan apa yang tepat untuk dapat dijadikan sebagai background dalam penelitiannya.

d. Hastag 
Hastag adalah fitur yang dimiliki Instagram yang bermanfaat agar suatu konten dapat menjangkau lebih luas targetnya, karena melalui hastag seorang konsumen tanpa harus mengetahui nama Instagram Kiddiposh tetapi cukup hanya dengan mencari hastag yang sama dengan yang ada pada setiap postingan Kiddiposh.

e. Fitur like, comment, dan share

Fitur ini menjadi fitur yang paling diperhatikan oleh konsumen. Semakin banyaknya like maka akan memberikan kepercayaan kepada konsumen bahwa Kiddiposh merupakan usaha yang menjual produk perlengkapan ibu dan anak dengan kualitas yang baik. Selain itu, comment juga dapat menggambarkan hubungan Kiddiposh dengan para konsumen, melalui fitur comment Kiddiposh juga dapat memperoleh informasi lebih terkait apa yang menjadi trand dan kesukaan konsumen.

Sudah memiliki kepercayaan dengan Kiddiposh akan memberikan rekomendasi kepada lingkungan terdekatnya bahwa Kiddiposh merupakan toko yang menjual produk perlengkapan bayi. Fitur yang digunakan untuk membagikan postingan Kiddiposh kepada orang lain adalah fitur share.

Semakin banyak postingan yang dishare konsumen, maka semakin bertambah pula jangkauan pasar yang akan dicapai Kiddiposh.

3. Shopee Kiddiposh

Marketplace menjadi salah satu media yang juga dapat dimanfaatkan oleh Kiddiposh karena tanpa harus mengeluarkan biaya tempat, Kiddiposh akan mampu menjangkau konsumennya. Shopee memiliki beberapa kategori produk dan Kiddiposh termasuk kedalam kategori produk Ibu dan Anak.

Kiddiposh menampilkan beberapa produk dalam bentuk foto dan video disertai dengan deskripsi singkat produk dan harga yang ditawarkan. Konsumen Kiddiposh yang merasa nyaman dalam menggunakan marketplace shopee karena kemudahan dalam proses pembelian, serta fitur-fitur lainnya yang ada di shopee. Fitur yang dapat dirasakan konsumen saat membeli produk Kiddiposh melalui shopee adalah voucher gratis ongkir, pembayaran menggunakan shopee pay later, jaminan pengembalian, dan jasa pengiriman yang secara langsung dapat konsumen tentukan.

Kiddiposh memulai usahanya langsung melalui E-Commerce dengan memanfaatkan media website dan social media.

Alasan Kiddiposh memulai usahanya dengan menggunakan fasilitas E-Commerce didukung oleh pendapat Morissan yaitu

1. Dapat menjangkau audiencesi diseluruh dunia.

2. Dapat melakukan komunikasi interaktif dengan biaya yang efisien 
3. Dapat menjangkau target konsumen tertentu.

4. Lebih mudah menyampaikan perubahan informasi seperti perubahan harga atau informasi lainnya.

5. Meningkatkan pelayanan kepada pelanggan karena tersedia akses selama 24 jam, tujuh hari seminggu.

6. Mendapatkan umpan balik segera dari konsumen

7. Merupakan saluran distribusi alternative Menyediakan biaya penyebaran informasi merek yang efektif dan efisien.

Peningkatan penjualan menjadi hal utama yang diharapkan oleh pengelola Kiddiposh setelah dilakukannya berbagai strategi pemasaran melalui $E$ Commerce.

Berdasarkan data penjualan Kiddiposh, sejak tahun 2019 hingga saat ini penjualan produk Kiddiposh mengalami peningkatan yang cukup signifikan. Secara rinci kunjungan konsumen pada media E-Commerce Kiddiposh dengan jumlah pembelian yang dilakukan pembeli dapat dilihat pada Tabel 1.

Tabel 1. Data kunjungan media pemasaran dan penjualan Kiddiposh

\begin{tabular}{lllll}
\hline Tahun & $\begin{array}{c}\text { Traffic } \\
\text { sessions } \\
\text { per day }\end{array}$ & $\begin{array}{c}\text { Traffic } \\
\text { sessions } \\
\text { per day }\end{array}$ & Purchase & $\begin{array}{c}\text { Item } \\
\text { Purch }\end{array}$ \\
\hline 2019 & 644 & 19.650 & 220 & 478 \\
2020 & 989 & 30.163 & 494 & 1.193 \\
2021 & 1.365 & 41.724 & 625 & 1.296 \\
\hline
\end{tabular}

Sumber : Data primer, 2021.

Kiddiposh mengalami peningkatan kunjungan konsumen pada media ECommerce yang dimiliki Kiddiposh yaitu website, Instagram dan Shopee. Semakin banyaknya kunjungan konsumen, maka semakin besar kemungkinan juga konsumen akan melakukan pembelian.

Berdasarkan Tabel 1 diketahui pembelian yang dilakukan konsumen mengalami peningkatan yang signifikan yaitu pada tahun 2019 sebanyak 220 dengan 478 item yang dibeli, kemudian naik menjadi 494 atau 2 kali lipat lebih banyak dari penjualan ditahun 2019, dan pada tahun 2021 kembali mengalami peningkatan menjadi 625 pembelian atas 1.296 item.

Peningkatan penjualan yang dirasakan oleh Kiddiposh dapat menggambarkan bahwa adanya respon yang baik atas produk yang dijual oleh Kiddiposh.

Namun, meskipun demikian nilai penjualan untuk setiap tahunnya masih harus dapat ditingkatkan.

Kiddiposh dapat melakukan kegiatan promosi lainnya atas produk yang ditawarkan, agar jangkauan konsumen menjadi lebih besar lagi dan penjualan mengalami peningkatan. Promosi yang dapat dilakukan oleh Kiddiposh adalah beriklan secara berbayar pada beberapa media E-Commerce 
khususnya Instagram dan Shopee, serta dapat juga melakukan kerjasama dengan tokoh influencer yang sesuai dengan karakteristik konsumen Kiddiposh, seperti influencer yang menjadi ibu dan sedanghamil untuk melakukan promosi secara pribadi (endorsement).

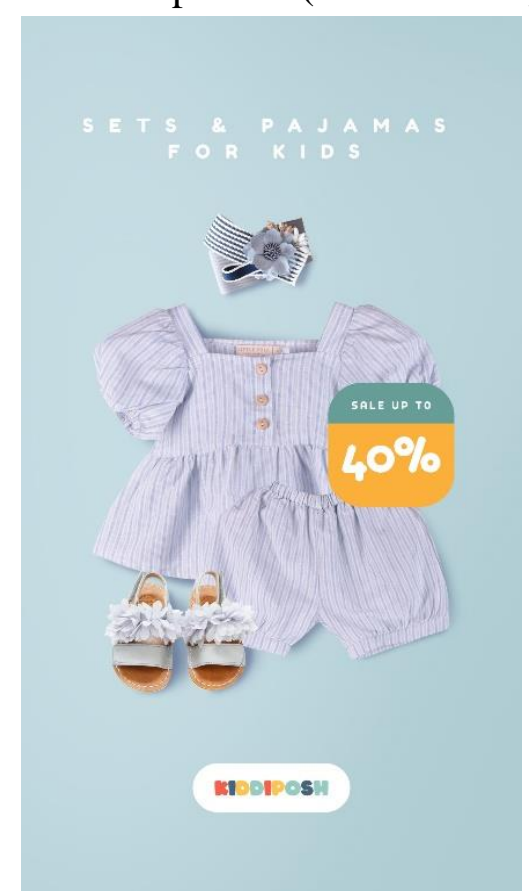

Gambar 3. Desain produk Kiddiposh

\section{Kesimpulan}

Kesimpulan dalam penelitian ini adalah 1. Kiddiposh memanfaatkan website sebagai salah satu sarana pemasarannya yang dapat diakses pada www.kiddiposh.com. Website yang terdiri dari server web, server aplikasi, dan server basis data sangat memiliki peluang dalam mendukung peningkatan penjualan dan mencapai target pasar Kiddiposh. 2. Instagram menjadi salah satu sarana pemasaran yang digunakan Kiddiposh yang memberikan pengaruh paling besar karena konten yang dihasilkan mampu menarik perhatian konsumen. Konten tersebut yang terdiri dari giveaway, video reels, quiz interaktif, sesi tanya jawab, dan sebagainya. 3. Shopee Kiddiposh termasuk kedalam kategori produk Ibu dan Anak dengan menampilkan beberapa produk dalam bentuk foto dan video disertai dengan deskripsi singkat produk dan harga yang ditawarkan, sehingga memberikan kemudahan dalam proses pembelian, serta tawaran voucher gratis ongkir, pembayaran menggunakan shopee pay later, jaminan pengembalian, dan jasa pengiriman yang secara langsung dapat konsumen tentukan. 4. Statistic kunjungan konsumen pada media E-Commerce Kiddiposh mengalami peningkatan setiap tahunnya. Hal tersebut diikuti dengan peningkatan penjualan produk Kiddiposh yang signifikan pada tahun 2019 hingga 2021. 


\section{Bibliografi}

Alyusi, Shiefti Dyah. (2019). Media sosial: Interaksi, identitas dan modal sosial. Prenada Media.

Augustinah, F. (2019). Pemanfaatan Media Sosial sebagai Sarana Promosi Makanan Ringan Kripik Singkong di Kabupaten Sampang.

Cicik Harini, M. M. (2020). Strategi Pemasaran Kewirausahaan UMKM. Media Sains Indonesia.

Haryono, Sugeng. (2018). Pengaruh penggunaan website terhadap penjualan produk pengusaha UMKM pada asosiasi industri kreatif Depok. Sosio E-Kons, 10(1), 3946.

Hastanti, Rulia Puji, \& Purnama, Bambang Eka. (2015). Sistem penjualan berbasis web (e-commerce) pada tata distro kabupaten pacitan. Bianglala Informatika, 3(2).

Kotler, Philip, \& Keller, Kevin Lane. (2016). A framework for marketing management. Pearson Boston, MA.

Moleong, Lexy J. (2007). Metodologi penelitian kualitatif edisi revisi.

Nursalam, Nursalam, \& Arifin, Jamaluddin. (2016). Konstruksi Sosial Media Komunikasi Instagram Terhadap Pola Pikir Perilaku Mahasiswa Pendidikan Sosiologi. Equilibrium: Jurnal Pendidikan, 4(2).

Pramudita. (2019). Pengaruh Insight Media Sosial Instagram Terhadap Penjualan Produk Online. Jurnal Riset Bisnis Dan Manajemen, 10(1), 1-14.

Puspitarini, Dinda Sekar, \& Nuraeni, Reni. (2019). Pemanfaatan Media Sosial Sebagai Media Promosi. Jurnal Common, 3(1), 71-80.

Radjaban, Radjaban, Dewi, Septi Riana, \& Rianto, Rianto. (2021). IMPLEMENTASI WEBSITE UNTUK MENINGKATKAN OMSET PENJUALAN BATIK BERKAH LESTARI. KACANEGARA Jurnal Pengabdian Pada Masyarakat, 4(1), 41-50.

Sedana, I. Made. (2019). Guru Dalam Peningkatan Profesionalisme, Agen Perubahan Dan Revolusi Industri 4.0. Jurnal Penjaminan Mutu, 5(2), 179-189.

Siswanto, Tito. (2013). Optimalisasi sosial media sebagai media pemasaran usaha kecil menengah. Liquidity, 2(1), 80-86.

Sukmadinata, Nana Syaodih. (2011). Metode Penelitian dan Pendidikan. Bandung: PT Remaja Rosdakarya.

Suryani, Ita. (2014). Pemanfaatan media sosial sebagai media pemasaran produk dan 
AnggunA’yunn Angraeny, Adrian Alexander Suripatty

potensi Indonesia dalam upaya mendukung ASEAN community 2015.(Studi Social media marketing pada twitter kemenparekraf ri dan facebook disparbud provinsi jawa barat). Jurnal Komunikasi, 8(2), 123-138.

Susanto, Aris. (2013). Penggunaan Web Sebagai Salah Satu Pendukung Strategi Pemasaran Produk Oleh Perusahaan Kusuma Agro Industri Batu. Jurnal Administrasi Bisnis, 5(2).

Syahputro, Eko Nur. (2020). Melejitkan Pemasaran UMKM melalui Media Sosial. Caremedia Communication.

Wanda, Sulistianto Sutrisno. (2017). Efektivitas Pemanfaatan Website dalam Rangka Promosi Produk dan Peningkatan Penjualan Studi Kasus PT. Amonindo Utama. 